\title{
The Natural Gas Addiction and Wood Energy Role in Latvia Today and Future
}

\author{
Ginta Cimdina, Andra Blumberga, Ivars Veidenbergs, Dagnija Blumberga, Aiga Barisa \\ Institute of Energy Systems and Environment \\ Riga Technical University \\ Riga, Latvia
}

Received: February 26, 2021 Revised: March 19, 2021. Accepted: March 22, 2021. Published: March 29, 2021.

\begin{abstract}
The paper analyzes strategies for restricting Latvia's dependence on fossil fuel imports in line with an increasing challenge to follow the leading EU Member States in greening the energy sector. Availability of local biomass resources ensures the necessary framework for building an arranged, environmentally and climate-friendly economy. Primary attention is paid to historical pattern of wood fuel use which shows reduction in wood fuel's share of primary energy consumption, however energy efficiency improvement is not observed. A hypothesis for development of wood fuel consumption up to 2020 is proposed. Analysis indicates potential of reaching a $43 \%$ share of wood fuel in national energy mix by 2020.
\end{abstract}

Keywords-Wood fuel, green growth, primary energy use, hypothesis

\section{INTRODUCTION}

Transition from fossil fuel-based to renewable energy systems is challenging both at the European Union (EU) and Member State level. Over the past decade, leading Member States of the EU have taken practical steps to introduce the concept of energy sustainability in their political agendas by developing and adopting national long-term energy strategies, see, e.g. [1, 2]. Particular attention is paid to feasible utilization of available bioenergy (and especially wood fuel) potential as the first step towards increasing the share of energy produced from renewable sources in the national energy mix $[3,4]$.

In terms of environmental, economic and technological provisions, Latvia has all the necessary preconditions to follow the challenge of leading European countries and build an arranged, environmentally and climate-friendly economy. Four types of international commitments directly impact Latvia's orientation towards green growth:

- Obligation to improve end-use energy efficiency by at least $9 \%$ by 2016 compared to 2009 level in the framework of the National Energy Efficiency Plan;

- Obligation to increase the share of renewable energy sources (RES) in final energy consumption by $40 \%$ by 2020 according to Directive 2009/28/EC (33.6\% in 2010);

- Obligation to meet at least $10 \%$ RES share in the transport sector by 2020 under the Directive 2009/28/EC (3.3\% in 2010), and;

- Obligation to reduce greenhouse gas (GHG) emissions by $21 \%$ over the period 2013-2020 compared to 2005 level among participants of the EU Emissions Trading Scheme
(ETS) and allow no more than $17 \%$ GHG emission increase in sectors outside the EU ETS.

Currently increased attention of countries worldwide, including Latvia, is focused on two aspects of energy - energy dependence and climate change.

At the same time, scientists are engaged in research of the use of renewable energy resources and creation of new technologies. Such actions contribute to energy dependence on increase of imported energy.

Global experience has proven that increase in energy consumption causes energy deficit and government officials think about the increase of energy resource imports instead of reducing energy consumption.

Transition from a fossil fuel economy to a renewable energy economy is a complex process and requires a longterm development strategy and serious approach to its implementation.

It is hard to think in the long term when facing short-term problem - energy consumption increase. There is great temptation to solve this problem using the simplest of solutions - importing more energy. The more attention is paid to short-term solution, the less it is dedicated to the long term - the use of RES.

This problem (and other addiction problems) from the perspective of systemic thinking has been described by Peter Senge, who is one of the founders of systemic thinking. In his book „The Fifth Discipline. The Art and Practice of the Learning Organization" [5], published in 1990, he has developed several archetypes, one of which - "distraction" reflects the adverse effects of transport sector energy dependence and short-term planning in long-term:

- using symptomatic (short-term) solution, or;

- fundamental (long-term) solution.

The system archetype is schematically given in Figure 1, which illustrates a causal loop diagram. Archetype hypothesis - if a symptomatic solution is used at least once, this reduces the symptoms of the problem and the need to implement a fundamental solution. Using a symptomatic solution repeatedly, attention is averted from a fundamental solution. The symptomatic solution creates a side effect - by using it multiple times, the ability to apply the fundamental solution, for example, additional purchase of renewable energy in the situation of growing energy consumption, decreases. 


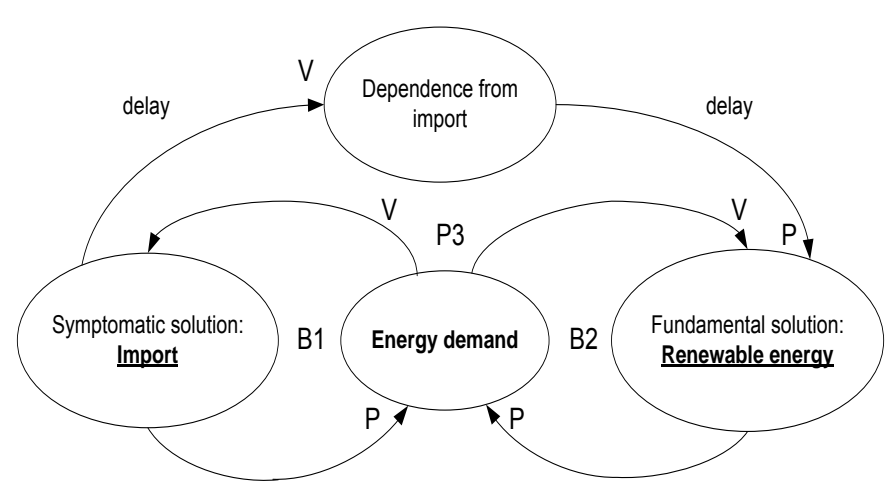

Fig.1. Causal loop diagram of the system archetype "distraction". (P contrary processes, $\mathrm{V}$ - equal processes, B1, B2 - balancing loops, P3 - a balancing loop, a delay - processes do not happen at the same time, but with a delay relative to one another)

The best illustration of the circumstance mentioned above is a specific situation with energy production from renewable energy resources in Latvia. Despite the fact that it is already possible to achieve $70-80 \%$ share of renewable resources in district heating energy supply in this decade, existing regulatory measures and policy instruments hinder this development. The government should change the existing mandatory procurement system, whereby the sources of renewable energy must compete on an equal basis with the fossil fuel-powered co-generation power plants. The energy tariffs of the natural gas cogeneration (condensation) stations incorporate their installation cost essentially discriminating against the set-up of renewable energy power stations.

\section{METHODOLOGY}

To transfer national economy from fossil to renewable primary energy resources it is necessary to define directions, objectives and principles for such transformation. The algorithm of methodology presents four modules as showed in Figure 2.

\section{A. Module 1. Tracks and directions}

Economically reasonable costs and technological development determines how to meet the commitment of the country and which are the priority sectors. Therefore, the strategy must have at least three parallel tracks, which both converge and classify, to achieve independence from fossil fuels.

\section{1) Track 1}

Transition to more energy-efficient energy consumption and use of renewable energy sources:

- more energy-efficient use of energy;

- increased use of biomass and biogas, and;

- more renewable wind energy offshore and on land.

\section{2) Track 2}

Integration of new solutions in the energy sector and transport system:

- green transport sector;

- new era of energy-policy management, and;

- transition from fossil fuels to independent energy systems in national and regional level.

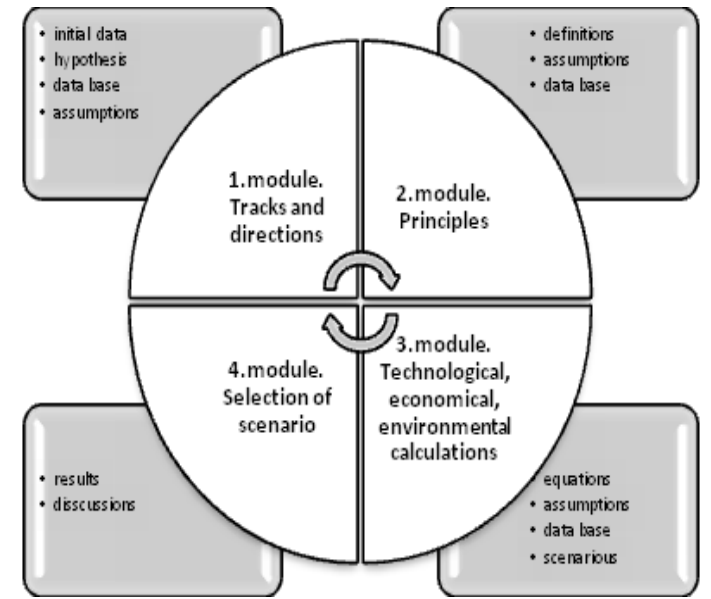

Fig.2 Algorithm of methodology

\section{3) Track 3}

Research, development and demonstration:

- national energy system modelling and establishment of development evaluation, control and monitoring system;

- comprehensive demonstration and preparation for a wide range of market demands. Integration in transport and energy systems, and;

- development of the green energy system based on research, demonstration and preparation for market demand.

One of the most important aspects determining the implementation of Track 1 is the availability of wood fuel resources in Latvia. Research results of forest specialists [6] show a high potential of bioenergy (see. Table I).

TABLE I WOOD FUEL RESOURCES

\begin{tabular}{|c|c|c|}
\hline Resources & $\begin{array}{c}\text { Potential } \\
\text { volumes, mil. } \\
\text { loose-m³/year }\end{array}$ & $\begin{array}{c}\text { Real volumes, } \\
\text { mil. loose- } \\
\text { myear }\end{array}$ \\
\hline Wood logs & 6.26 & 4.33 \\
\hline Forest residue & 6.80 & 4.70 \\
\hline Stems & 8.10 & 7.37 \\
\hline Other resources & 3.10 & 2.13 \\
\hline $\begin{array}{l}\text { Byproducts from wood } \\
\text { processing }\end{array}$ & 12.92 & 8.92 \\
\hline Total & 37.18 & 27.45 \\
\hline
\end{tabular}

\section{B. Module 2. Principles}

The principles incorporated in the Green Energy Development Strategy of the national energy industry sector comprise financial, environmental, climate, socio-economic and management aspects.

\section{1) Cost Efficiency}

Cost efficiency measures are economically justified; they ensure a maximum energy supply security and a high reduction of the use of fossil fuel in relation to each LVL invested. Consequently, there is no emphasis on large-scale equipment requiring high investment.

Contrary to the use of expensive technologies, full attention should be paid to research, development and demonstration 
which could increase the competitiveness of these technologies long-term with lower inputs.

\section{2) Minimum Impact on Public Funding}

The cost and benefit distribution for transition to the socalled Green Growth should not cause adverse effects on the government budget. All outlays should be fully covered by consumers of energy resources (both, enterprises and households).

\section{3) Renewed Competitiveness.}

When implementing the transition to Green Growth, the impact the latter will exercise on the competitiveness of the business environment in Latvia should be noted. The mechanisms of price and tariff formation and factors influencing them should be transparent and predictable in the long-term to facilitate making the relevant decisions for consumers and investors targeted at further growth.

\section{4) Flexibility Principle}

The forecasts of energy sector development are based on regular analyses of the operation and management of the energy sector, furthermore, implementation of new technology solutions should be adjusted to processes taking place in the European Union and global energy market, e.g., in case of the price increase for biogas, a transition should be made to less costly renewable resources (wind, solar power, etc.) with the help of higher investment.

\section{5) Full-bodied Use of International Cooperation}

The transition process should make use of all opportunities available globally and within the European Union. An isolated country from the power resource point of view is not our goal. Latvia should start the uptake of advantages offered by the international market.

\section{6) Security of the Energy Supply System}

There should be a secure national energy supply system in place; however ensuring security measures must be commercially justified. The current practice of achieving security through investment into high power energy units should be discontinued. The security of energy supply must be achieved through modern diffused production and smart network technologies. Energy prices will be stabilised by lower primary power consumption and essential reduction of fossil fuel.

\section{7) Bottom-up Model}

The involvement and activity modelling of every energy consumer is more suitable to Latvia's energy sector as a whole as it provides better opportunities for the implementation of realistic energy efficiency and renewable energy resources' projects on the consumer side, as well as achieve reduction of the use of fossil fuel.

\section{8) Support to Centralization Principle in Heating Supply}

A centralized heating supply through the heat load centres is commercially more advantageous and friendlier to the environment and climate than the construction of individual boiler systems for heating. The business economy principle should be observed, i.e., wholesale goods should cost less than retail goods.

\section{9) Flexibility of Energy Industry System}

Renewable resources that are commercially justified from the circulation cycle analysis point of view, as well as are environmentally and climate friendly should be selected. The amounts of their use should vary depending upon: prices, availability of resources, development of innovative technologies and impact on the climate change mitigation policies.

\section{0) Market Model}

During the period of transition to Green Growth, competitive electric power and energy resources' markets (e.g. natural gas) should be established. The progress of the country towards a united electrical energy market of the Nordic countries and towards a revision of the transmission system operator surcharges, which are higher in Latvia than in other countries, will make a beneficial impact on the competitiveness of this country.

\section{1) Business Model}

The production, management and marketing of the heating power and electrical power should be based on a business economy. Within the transition period to Green Growth, cofunding is available exclusively in case of full withdrawal of subsidies for fossil energy resources in any form of power production and transition to the use of renewable energy resources.

\section{2) Gradual Approach}

The issues related to the use of renewable energy resources and the increase of energy efficiency should be addressed step by step observing priorities and avoiding implementation of all measures simultaneously.

\section{3) Sustainable Development Model}

The development of an energy network system must be a long-term process thinking 30-40 years ahead in regard to natural resources, mitigation of the climate change, socioeconomic development etc.

\section{4) Level Mark Model}

The regulation model of heat energy tariff should be urgently adjusted to motivate owners of energy sources to increase energy efficiency and seek commercially sound solutions for the operation of energy sources. This would be a long-term approach

\section{5) Assessment Model}

In order to reach the desired result or implement intended measures, it is not enough to stop at setting the goal. Principle of good governance mode must be applied to analyse and assess the success of the intended operational measures and to make appropriate adjustments for further steps towards the Green Growth.

\section{Module 3. Calculations}

Technologies, which are now relatively expensive, can be very important in the long run. Among them are electric cars, solar energy, wind energy accumulation, as well as carbon capture and storage systems.

The relationship between biomass, wind and solar energy will depend on various factors which are currently not known. 
- Option 1: the amount of biomass will grow and it will alternatively 'not be costly'. This will reduce the need for wind energy.

- Option 2: increase in energy efficiency will not happen as planned. This will increase the need for larger amounts of biomass.

- Option 3: there is a rapid development of other renewable energy technologies. For example, the use of solar energy technology will become economically most advantageous.

All of this emphasizes the need for a flexible strategy, which ends with opportunities for technology development. Problems relevant to energy supply safety and impact on climate change can also be resolved in different ways.

This paper only presents results of Option 1 analysis (see below).

\section{Module 4. Selection of scenario}

Renewable energy development scenarios are affected by a variety of factors: distribution among different renewable energy sources, technology parameters, economic indicators etc.

In the period up to 2020 , the main emphasis must be on a more complete use of biomass, without neglecting the use of wind energy after 2020 and the use of solar energy primarily in multi-apartment houses, thus ensuring hot water supply.

\section{RESULTS AND DISSCUSSION}

\section{A. Analysis of results}

The distribution of renewable energy resources is evaluated on the basis of technological, economic and environmental aspects. Each type of renewable energy resource has its own niche both in respect to energy users, and the energy conversion and transmission aspect.

Accordingly, during the time period till 2020 wood energy will have the main role; therefore it is an important aspect to analyse. The use of wood energy mainly depends on the technological equipment and its energy efficiency.

Analysis of the current situation serves as raw data for prediction models. Statistical data are not only a source of information, but also provide development indicators for current technological solutions and for the development of state economy in general.

To understand the restrictions of wood fuel use in Latvian energy sector and develop a baseline upon which future vision is built, statistical data for last 4 years were analyzed.

As shown in Figure 3, data on annual primary energy consumption and energy end-use present maximum in 2010 followed by a decline afterwards. However import of primary energy increased dramatically by $21.6 \%$ in 2011 in comparison with the previous year. The same graph also shows Latvian energy resource production volumes, which have been holding at the same level in the last three years.

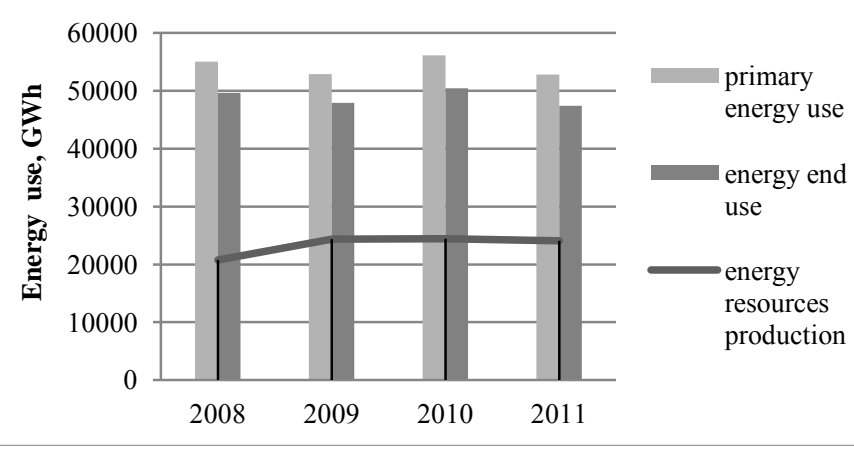

Fig.3 Changes in energy use in Latvia over the period 2008-2011 [6]

Reasons for the observed decrease in energy consumption in 2011 could be several. The most commonly agreed reason for this reduction is the improvements in energy efficiency introduced within the energy sector. Therefore energy efficiency of primary energy use in Latvia was determined and is presented in Figure 4.

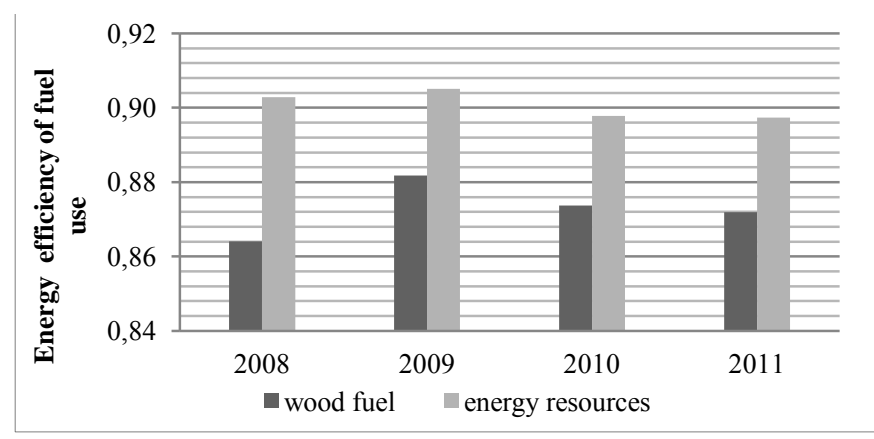

Fig.4 Energy efficiency of primary energy use in Latvia

Figure 5 illustrates relationship between the primary energy consumption during the period 2008-2011 and the efficiency of primary energy use.

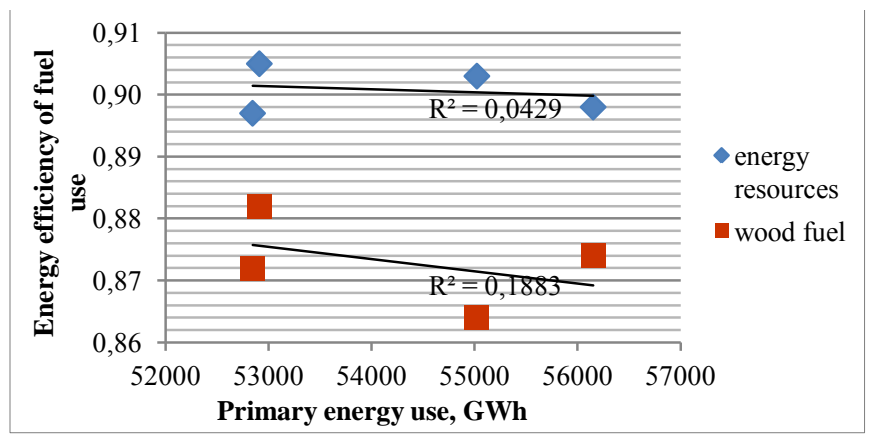

Fig.5. Relation between primary energy consumption and energy efficiency of fuel use

According to the results, the highest energy efficiency of primary energy use in the Latvian energy sector was reached in $2009,90.5 \%$ respectively. Meanwhile the lowest energy consumption was observed in 2011. A reduction in energy efficiency was observed in last two years (89.8\%). In 2011, as well the energy consumption decreased. Data in Figure 5 show weak correlation between the primary energy consumption and the efficiency of primary energy use. Results indicate that the reduction of primary energy consumption is not caused by 
a more efficient use of energy resources. Such tendencies state that the development of energy sector goes contrary to governmental statements.

A slightly different situation in the past years has emerged in relation to the use of wood energy in Latvia (see Figure 6). The maximum consumption of wood fuel was reached in 2009. An evaluation of the data illustrates an unprecedented decrease of wood fuel use in 2010 and 2011, which could be explained by the replacement of wood fuel with imported fossil fuel.

The energy efficiency of wood fuel use is less than that of primary energy use in the energy sector of Latvia. The highest energy efficiency of wood fuel use $(88.2 \%)$ was reached in 2009 (see Figure 4). Later on, in 2010 and 2011, a decrease in energy efficiency was observed $(87.2 \%)$. This means that the reduction of wood energy consumption cannot be explained by increased energy efficiency in the energy sector.

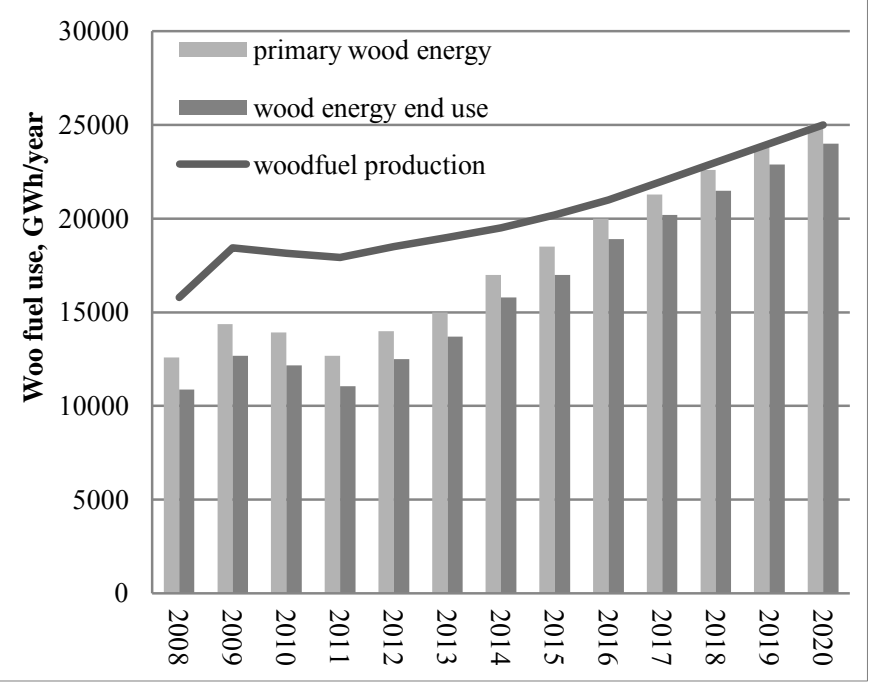

Fig.6. Wood fuel use in past and future in Latvia

\section{B. Hypothesis of wood energy development}

The matrix for creating a configuration of wood fuel development hypothesis is built on green growth calculation data. The test example presents results for Track1 and they are based on the principles $1,2,3,6,7,8,11$ and 15 from the above "Modules". The forecast of wood fuel production amounts and the share of wood fuel in primary energy consumption and energy end-use is presented in Figures 6 and 7. It presents future development scenario with a gradual growth in wood energy consumption.

Based on statistical data on historical wood energy consumption pattern, the share $(\%)$ of wood fuel in primary energy consumption for the last four years was determined. (see Figure 7). The difference in the shape of curves for wood fuel share in primary energy and energy end-use originates from changes in the amounts of supply and energy efficiency of wood fuel use. Mathematical modelling of the wood fuel share is based on green growth calculation data and results of historical wood fuel share assessment. A gradual step-by-step increase over the next years will allow reaching a $43 \%$ wood fuel share in energy end-use balance of Latvia.

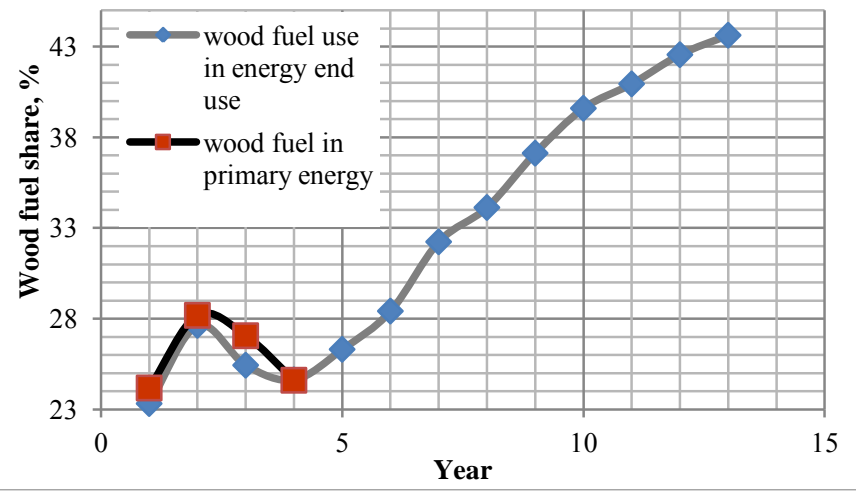

Fig.7. Historical data and forecast of wood fuel share

\section{CONCLUSIONS}

Analysis of the statistical data on annual consumption of primary energy resources and energy end-use in Latvia presents a maximum for both in 2010. However, the import of primary energy increased dramatically (21.6\%) in 2011 in comparison with the previous year. Volumes of primary energy resource production have been holding at the same level in the last three years. A decrease in energy efficiency of primary energy use is observed in the last two years $(89.8 \%)$. The reduction of primary energy consumption is not caused by more efficient use of energy resources, which is in conflict with governmental legislative documents.

Maximum consumption of wood fuel was reached in 2009. Evaluation of data illustrates unpredicted decrease in wood fuel consumption in 2010 and 2011, which could be explained by the replacement of wood fuel by imported fossil fuel. Energy efficiency of wood fuel use is less than that of primary energy use in the energy sector. The highest energy efficiency of wood fuel use in the Latvian energy sector was reached in $2009,88.2 \%$ respectively. Reduction of energy efficiency was observed in the last two years $(87.2 \%)$. This indicates that the decrease in wood energy consumption cannot be explained by improved energy efficiency in the energy sector.

Slow step-by-step use through the years will allow reaching a $43 \%$ share of wood fuel in the energy end-use balance of Latvia by 2020.

\section{REFERENCES}

[1] Energy Strategy 2050 - from coal, oil, gas to green energy. Summary The Danish government 2011, pp.15.

[2] Färdplan för ett Sverige utan klimatutsläpp 2050. Sammanfattning. 2013, pp. 5.

[3] E. Perednis, V. Katinas, A.Marcinkevicius, "Assessment of wood fuel use for energy generation in Lithuania" Renewable \& sustainable energy review Vol.16, Issue 7, pp 5391-5398, September 2012.

[4] K.Cemil (2011), A.Y. Balaban, "Wood fuel trade in European Union Biomass and Bioenergy" Vol. 35, Issue 4, pp 1588-1599, April 2011.

[5] Senge P. (1990). The Fifth Discipline. The Art and Practice of the Learning Organization, 1990.

[6] D.Dubrovskis (2011) Vietējo koksnes resursu mobilizācijas iespēju izvērtēšana jaunu augstākās pievienotās vērtības produktu un bioenerǵijas ražošanai Apvienotais pasaules latviešu zinātnieku 3 . Congress un letonikas 4.kongress. Tēžu krājums.

[7] Central Statistical Bureau of Latvia (2011). Energy - Key Indicators. 2011.

Creative Commons Attribution License 4.0 (Attribution 4.0 International, CC BY 4.0)

This article is published under the terms of the Creative Commons Attribution License 4.0

https://creativecommons.org/licenses/by/4.0/deed.en_US 